\title{
Interest Rate Pass-Through: Empirical Evidence from Pakistan
}

\section{Sheikh Khurram Fazal* and Muhammad Abdus Salam**}

\begin{abstract}
This article empirically examines the interest rate pass-through mechanism for Pakistan, using six-month treasury bills as a proxy for the policy rate (the exogenous variable) and the weighted average lending rate and weighted average deposit rate as endogenous variables representing the lending and deposit channels, respectively. We use data for a six-year period from June 2005 to May 2011, published by the central monetary authority in Pakistan. The widely accepted error correction mechanism is used to examine the short-run and longrun pass-through; a vector error correction mechanism impulse response function helps measure the short-run speed of the pass-through. We find that there is an incomplete pass-through in Pakistan for both the lending and deposit channels. The impact is greater on the lending channel than on the deposit channel in both the short and long run, while the adjustment speed is higher for the lending channel.
\end{abstract}

Keywords: Interest rate pass-through, interest rate channel, transmission mechanism, monetary policy, Pakistan.

JEL classification: E43, E58.

\section{Introduction}

In recent years, central banks in developed and developing countries have tended to use monetary policy to promote growth and stabilize the economy. Parkin (2005, p. 483) and Stanlake and Grant (2000, p. $317)$ observe that monetary policy attempts to change the interest rate and quantity of money supply to bring about the desired changes in the economy; it is formulated by the country's central monetary authority. Arby and Hanif (2010) add that the role of the government and fiscal policy plays an important role, where monetary policy requires the support of fiscal policy to maintain its effectiveness and the autonomy of the central bank.

\footnotetext{
* Mitsubishi Corporation, Karachi.

** State Bank of Pakistan, Karachi.
} 


\subsection{Monetary Policy Tools}

Monetary policy is considered one of the most influential tools used to affect growth, stabilize the price level, and control the economy's financial system. The State Bank of Pakistan (SBP) formulates and conducts the country's monetary policy, taking into consideration the current economic environment and future expectations about core economic variables such as output, inflation, and the exchange rate. The government, researchers, policymakers, and other stakeholders keep close watch over the SBP as it conducts monetary policy. The bank uses numerous monetary policy tools to stabilize and improve economic activity in Pakistan, some of which are listed below along with their rates:

- The discount rate (DR), policy rate, or reverse repo rate is the benchmark interest rate set by the SBP at which commercial banks and other depository institutions can borrow from the central bank on an overnight basis to meet their resource requirements. The DR in Pakistan is 14 percent (as on November 2010).

- Banks use the SBP's repo rate facility to park their excess cash reserves with the SBP on an overnight basis; it currently offers an 11 percent rate of return (as on November 2010).

- The minimum capital requirement (MCR) refers to the amount of net equity value of a bank's shareholders, after adjusting for losses (if any); this was PKR 7 billion as on December 2010, with PKR 8 billion to be maintained by December 2011 (State Bank of Pakistan, BSD Circular No. 07, 15 April 2009).

- Open market operations (OMOs) refer to the purchase or sale of government bonds or securities in the open market to inject or reduce excess money circulation in the commercial banks; in Pakistan, this is conducted by the SBP every fortnight.

- The cash reserve requirement (CRR) is the percentage of total demand deposits with less than a year's maturity that banks need to maintain on a weekly basis with the SBP, without any return being paid by the central bank. In Pakistan, it stands at 5 percent of the total deposits as of November 2008.

- The statutory liquidity reserve (SLR) requirement is the percentage of total demand deposits with less than a year's maturity that banks are 
required to hold in government securities (excluding CRR); this currently stands at 19 percent for all banks in Pakistan as of June 2011. Earlier, Islamic banks were required to maintain 14 percent in SLR instead of the current 19 percent level.

- Letter of credit margin (LCM) is a proportionate value of importable goods that importers must deposit in their banks as a cash margin to avail credit from the bank to import cargo. This varies from commodity to commodity in Pakistan.

- The export refinancing rate (ERR) is the rate at which an exporter in Pakistan can borrow from the commercial banks at a subsidized rate. It is linked to the last three auctions' weighted average yields of sixmonth treasury bills (TB6M) against future export proceeds; is the ERR currently hovers around 10 percent.

- Moral suasion usually refers to cases where the central bank persuades commercial banks to lend smaller funds to borrowers.

The classical tool for achieving macroeconomic goals in monetary theory is the policy rate or DR, which is determined by the monetary authority's board of governors, based on macroeconomic activity and the health of the economy. The DR is highly instrumental in influencing various market rates, which in turn affect the factors of economic activity directly or indirectly with a certain time lag, depending on the size of shocks, the prevailing economic environment, retail market or banking industry competition, the risk appetite of creditors and depositors, and the degree of economic openness.

Stanlake and Grant (2000, p. 319) define monetary policy transmission as the passing of policy shocks to economic variables and the time taken by these shocks to affect economic variables such as output and price level to improve the monetary system's health in the economy. In recent studies, more emphasis has been given to the effect of short-term interest rates, with the core objective of stabilizing real output, inflation, the exchange rate, unemployment, and other economic variables.

\subsection{Research Problem}

According to the literature, most central banks have identified a positive significant relationship between the DR and market interest rates, 
especially for the deposit channel of interest rate pass-through (the time and magnitude of impact on financial market retail rates, namely deposit and lending rates, in response to a change in the policy rate). In Pakistan, the central bank has effected several structural changes to improve the effectiveness of its monetary policy transmission mechanism over the last five years. This study aims to examine empirically the impact of policy shocks on the market retail lending and deposit rates in Pakistan.

\subsection{Research Objective}

Our main objective is to empirically examine if there is a significant impact on the retail lending and deposit rates in response to a policy rate decision or shock, along with its magnitude in the short and long run and the speed of pass-through from a policy shock to retail rates in the short run.

\subsection{Importance of the Study}

This quantitative research will help understand whether the Keynesian perspective on the key interest rate pass-through mechanism in Pakistan is effective for market lending and deposit rates, i.e., how significantly the response to a decision on the policy rate proxy (TB6M) is transferred to the market lending and deposit rates. There is evidence of a higher pass-through into the lending channel than the deposit channel. The speed of the pass-through is also greater for market lending rates in the short and long run compared to market deposit rates.

The remainder of the article is organized as follows. Section 2 reviews the relevant literature, and is followed by a theoretical and conceptual framework in Section 3. Section 4 details the research methodology used. Section 5 presents and discusses the data and estimation results. Sections 6 and 7 provide a conclusion and policy recommendations, respectively.

\section{Literature Review}

Monetary authorities across the world have striven to enhance the effectiveness of monetary policy and the responsiveness of economic variables to policy decisions, especially after the global financial crisis that affected both developed and developing economies. Mishkin (1996) 
describes the different monetary policy channels, with an emphasis on the interest rate, exchange rate, equity price, and bank lending channels. Takim (2011) states that the interest rate channel is based on the Keynesian IS-LM perspective of monetary transmission mechanisms. Emphasizing the traditional interest rate channel, Mishkin (1996) explains that an expansionary policy decreases the nominal and real interest rates, in turn decreasing the cost of capital, increasing aggregate demand, and increasing the level of output.

Other channels identified include the expectations channel, which is considered to be closely associated with the interest rate channel. DablaNorris and Floerkemeier (2006) and Takim (2011) explain that the expectations channel relies on the central bank's inflation targeting regime by changing key interest rates; this directs economic agents' future outlook on the economy. Dabla-Norris and Floerkemeier (2006) stress that, if the expectations channel is effective, it signals the higher credibility of the central bank. Additionally, Takim (2011) argues that the interest rate channel holds on the basis that inflation expectations do not change in the economy. Horváth and Maino (2006) examine the economy of Belarus and confirm that the expectations channel seems to have played an important role in curbing the price level, based on its strong influence over economic activity, which allows it to act as a nominal anchor.

Bernanke and Blinder (1992) empirically examine the US economy using a vector autoregressive (VAR) impulse response function (IRF). They find that the fund rate is a good measure of monetary policy shocks, where loans respond comparatively slowly to deposits, as the rate is fixed for the contracted period of the loan.

Hofmann and Mizen (2004) investigate the base rate pass-though to retail rates in the UK, using 17 years' data on several deposit and mortgage rates. They find that there is a complete pass-through in the long run from the policy rate to the DR as compared to an incomplete pass-through to the mortgage rate. In a study on interest-based deposit and credit products, Fuertes, Heffernan, and Kalotychou (2008) present similar findings for the UK. They use a conventional nonlinear and linear error correction mechanism (ECM) to determine the adjustment speed of various UK bank retail rates, and find that the change in speed differs in proportion to the magnitude of a policy shock. They also find that deposit rates tend to 
adjust faster during monetary expansion, while mortgage rates tend to adjust more rapidly during monetary contraction.

Examining Turkey's economy, Aydin (2010) investigates the lending side and finds that the pass-through is higher for all types of loans. Consumer lending rates tend to be of a higher magnitude than corporate lending rates, and the pass-through in cash and automobile loans is also completed after a credit boom. Using an ECM to analyze Romania's interest rate pass-through, Tieman (2004) finds that deposit rates tend to respond quicker than lending rates, with the pass-through increasing gradually over time. In relation to Armenia's economy, Dabla-Norris and Floerkemeier (2006) find that, on average, lending rates respond instantaneously to a change in the policy rate, although the interest rate elasticity is expected to be low due to less banking competition in the country.

Examining Jordan's economy Poddar, Sab, and Khachatryan (2006) apply a VAR model to the real three-month certificate of deposit rate as a benchmark of policy shocks to determine the real retail rate's reaction within the same month. They find that deposit rates react at a higher magnitude of $92 \mathrm{bps}$, compared to $74 \mathrm{bps}$ for lending rates. Al-Mashat and Billmeier (2007) find that the interest rate channel remains weak in Egypt because of the higher interest spread of the banking industry, due mainly to low banking competition in the country's financial system.

Generally, researchers have found that, once the central bank changes the policy rate, it is reflected in the short-term market rate with a certain time lag depending on the prevailing economic environment. Qayyum, Khan, and Khawaja (2005) examine the interest rate pass-through for Pakistan's economy, applying the autoregressive distributed lag (ARDL) econometric technique to the TB6M yield rate as a benchmark of policy shocks. They find that complete pass-through occurs for the call money (CM) rate, with a mere 18 bps impact on the savings deposit (SD) rate in six months, but there is no pass-through in the six-month SD rate and weighted average lending rate (WALR) during the first six months of a policy shock. However, their study is limited in terms of methodology, analysis, and reporting; specifically, it uses monthly data for the TB6M and $\mathrm{CM}$ rates and six-monthly data for the other variables. This reduces the amount of variation in the data and information contained theirin, and makes it difficult to generalize the findings. Although they claim that high- 
frequency data should be used for such analysis, they have used two different data series with low-frequency data.

\section{Theoretical Framework}

Based on Mishkin (1996) and Takim (2011), we deduce that a contractionary monetary policy increases the short-term nominal and real interest rates, raises the lending rates to the private sector, leads to a higher cost of capital for firms, and reduces their demand for investment spending. This, in turn, reduces aggregate demand in the economy with the target of curbing inflation, ceteris paribus. This is expressed as:

$$
\mathrm{M} \downarrow \rightarrow \mathrm{DR} \uparrow \rightarrow \uparrow \mathrm{L} \rightarrow \uparrow \mathrm{CC} \rightarrow \downarrow \mathrm{IS} \rightarrow \downarrow \mathrm{AD} \rightarrow \downarrow \mathrm{INF}
$$

where $\mathrm{M} \downarrow$ indicates the contractionary monetary policy, DR $\uparrow$ indicates an increase in the DR, $\uparrow \mathrm{L}$ indicates an increase in the nominal and real lending rates, $\uparrow C C$ shows the increase in the cost of capital, $\downarrow$ IS indicates a decrease in investment spending demand, $\downarrow$ AD represents the decrease in aggregate demand in the economy, and $\downarrow$ INF indicates a decline in inflation.

Mishkin (1996), Agha, Ahmed, Mubarik, and Shah (2005), and Takim (2011) argue that a contractionary monetary policy simultaneously creates incentive for banks and financial intermediaries to earn higher returns by investing more in virtually risk-free government securities rather than catering to medium- to high-risk private sector credit demand. This increases their demand for deposits, such that they offer a higher deposit return rate, giving depositors incentive to enhance their banking deposits by delaying consumption spending to earn a higher return. Ultimately, this reduces aggregate demand in the economy with the main target of curbing inflation, ceteris paribus:

$$
\mathrm{M} \downarrow \rightarrow \mathrm{DR} \uparrow \rightarrow \uparrow \mathrm{D} \rightarrow \uparrow \mathrm{DEP} \rightarrow \downarrow \mathrm{AD} \rightarrow \downarrow \mathrm{INF}
$$

where $\mathrm{M} \downarrow$ indicates the contractionary monetary policy, DR $\uparrow$ indicates an increase in the DR, $\uparrow \mathrm{D}$ represents an increase in the nominal and real deposit rates offered to depositors, $\uparrow$ DEP indicates an increase in the quantum of financial deposits, $\downarrow$ AD represents a decrease in aggregate demand in the economy, and $\downarrow$ INF indicates a decline in inflation. 


\subsection{Conceptual Framework}

Qayyum et al. (2005), Aydin (2010), and Poddar et al. (2006) stress that a contractionary monetary policy that increases the policy rate (reflected in the t-bill yield) also affects the market lending rate, thereafter affecting the demand for investment credit, investment spending, and output, ceteris paribus:

$$
\mathrm{M} \downarrow \rightarrow \mathrm{DR} \uparrow \rightarrow \mathrm{TB} \uparrow \rightarrow \uparrow \mathrm{MLR}
$$

where $\mathrm{M} \downarrow$ indicates the contractionary monetary policy, DR $\uparrow$ indicates an increase in the $\mathrm{DR}, \mathrm{TB} \uparrow$ represents an increase in the $\mathrm{t}$-bill yield, and $\uparrow \mathrm{MLR}$ indicates an increase in market lending rates.

Tieman (2004), Poddar et al. (2006), and Fuertes et al. (2008) explain that a contractionary monetary policy gives banks and financial intermediaries incentive to earn a higher (almost) no-risk return on investment, thereby increasing their demand for public deposits. This implies that they will offer depositors a higher deposit return, thereby affecting consumption demand and output in the economy, ceteris paribus:

$$
\mathrm{M} \downarrow \rightarrow \mathrm{DR} \uparrow \rightarrow \mathrm{TB} \uparrow \rightarrow \uparrow \mathrm{MDR}
$$

where $\mathrm{M} \downarrow$ indicates the contractionary monetary policy, DR $\uparrow$ indicates an increase in the $\mathrm{DR}, \mathrm{TB} \uparrow$ represents an increase in the t-bill yield, and $\uparrow \mathrm{MDR}$ represents an increase in the market deposit rates offered to depositors.

\subsection{Hypotheses}

Our two hypotheses are:

H1: The policy rate does not affect market lending rates in Pakistan.

H2: The policy rate does not affect market deposit rates in Pakistan.

The first hypothesis (H1) determines whether the policy rate has a significant impact on the incremental and outstanding WALR. The second hypothesis $(\mathrm{H} 2)$ tests whether the policy rate has a significant impact on the incremental and outstanding weighted average deposit rate (WADR). Based on the theoretical and conceptual frameworks we use, the policy rate should have a significant impact on the market retail rates-implying that 
we can reject these hypotheses - and the relationship should be positive for all four market retail rates being considered.

\section{Research Methodology}

This is a quantitative study and in examining the interest rate passthrough under the recent contractionary monetary policy regime, we use secondary data published by the SBP for our empirical analysis, estimations, and model selection. The main reason for selecting the contractionary monetary policy stance is to determine whether the current policy-based interest rate shocks are reflected in the market retail rates. Time-series data on incremental and outstanding market retail rates is available for the period January 2004 onward, so the earlier period is not included. Additionally, the SBP's expansionary policy stance rapidly changed into a contractionary policy stance from late 2004 and early 2005; such transitional and highly volatile interest rate values tend to affect estimations and results.

\subsection{Choice of Variables}

We attempt to empirically explain the phenomenon of interest rate pass-through, using the TB6M (a proxy for the policy rate or DR) as an exogenous variable. This is mainly because the monetary policy was announced twice a year during the earlier years, implying that the DR would become a discrete variable until a change in it was announced. This can affect the estimation results due to the change in the frequency of variables in the model. Additionally, the market rates remain dynamic while there is no change in the DR, making it likely that we would lose important information prevailing in the financial market. Therefore, it becomes important to match the variables' frequency and introduce variability to incorporate financial market information impacts on interest rates.

A number of studies prefer using the interest rate policy proxy. Bernanke and Blinder (1992) find that the federal fund rate is a good proxy for the policy rate, while Agha et al. (2005), Qayyum et al. (2005), and Javid and Munir (2010) use the TB6M as a proxy for the DR in examining the monetary policy transmission mechanism of Pakistan's economy. We follow suit and use the TB6M as a proxy for the DR because the TB6M weighted average yield is derived by the SBP itself while carrying out OMOs 
fortnightly, mainly to support the government in fiscal deficit financing, to limit government borrowing from the central bank, and to reduce the excess liquidity available in the financial market by selling government bonds in which banks are the predominant participants. Additionally, since OMOs are conducted fortnightly, the formulation of the TB6M monthly series requires averaging two values every month in most cases.

Based on the theory, the lending rate is the markup paid by borrowers to the bank (lender) for the credit provided, while the DR is the return paid by banks to their depositors. The endogenous variables for the market lending rate include the WALR gross disbursements ${ }^{1}$ (incremental loans) and WALR total outstanding loans by all banks, including zeromarkup loans. For the market deposit rates, we use the WADR fresh deposits $^{2}$ (incremental deposits) and WADR total outstanding deposits by all banks, including zero-markup deposits.

The formula for calculating the weighted average rate is:

Weighted average rate $=\sum$ (rate $x$ amount $) \div \sum$ (amount)

\subsection{Data}

Our data on the variables above spans six years, comprising 72 observations from June 2005 to May 2011, published by the SBP and available online. The literature varies on the number of observations to be used in such an analysis but requires the data to be asymptotic (technically, constituting a large sample). Our observations are considered asymptotic based on Gujarati and Sangeetha's (2007, p. 485) criterion that data comprising 50 or more observations is considered reasonably large. Selvanathan, Selvanathan, Keller, and Warrack (2004, p. 772) state that the difference between the R-squared and adjusted R-squared terms should be a minimum, giving the example of a difference of 0.037 as being moderately good. We use a higher benchmark difference-a 0.010 difference that is appropriate to the sample size and is well within the benchmark. Hence, our sample size is reasonable for empirical analysis purposes.

\footnotetext{
${ }^{1}$ Gross disbursements are incremental disbursements rolled over or repriced either in Pakistan rupees or in foreign currencies during the month. For running finance, the maximum credit facility availed at any point during the month by the borrower is included.

${ }^{2}$ Fresh deposits are newly opened accounts and rolled-over or repriced deposits during the month.
} 
Adjustments in Data

Data on the market lending and deposit rates is available on a monthly basis, compared to data on the TB6M, which is available more frequently, being dependant on the auction conducted by the SBP every $14^{\text {th }}$ day. In order to ensure homogeneity and balance among the variables' frequency, we adjust the TB6M data by taking the simple average of the TB6M weighted average yields in the month they were conducted. Thus, if there were two OMOs in a month, then the sum of yields is divided by 2 to calculate the simple average yield or the yield rate for the month or, as the case may be, depending on the number of OMOs conducted in a month.

\subsection{Model Selection}

Based on an understanding of the literature and the simplicity of the empirical analysis, we use the least squares method. After examining the classical linear regression model (CLRM) assumptions, where CLRMestimated parameters provide the long-run magnitude of the interest rate pass-through, we determine the presence of a unit root in the individual time series using the augmented Dickey-Fuller (ADF) test. This indicates that the ECM and vector error correction mechanism (VECM) models should be applied to empirically examine the short-run dynamics.

Prior to this, a two-step Engle-Granger test (EG) (see Engle \& Granger, 1987) is applied to confirm the cointegration between the variables of the equation and the long-run relationship between the model's variables. We use the ECM and VECM IRF with an errors-reduced form of Cholesky decomposition (see Sims, 1980) to estimate the short-run magnitude and speed of the pass-through.

\section{Data Analysis and Estimation}

The secondary data on the variables is used to estimate the CLRM. Initially, we test the CLRM assumptions based on the following econometric equations for the lending and deposit channels:

Lending $\quad W A L R=\beta_{1}+\beta_{2} T B 6 M+u l_{t}$

Deposit $\quad W A D R=\beta_{3}+\beta_{4} T B 6 M+u d_{t}$ 
where the $\beta$ terms are the estimated parameters, and $u l_{t}$ and $u d_{t}$ are the error terms from the lending and deposit channel equations, respectively. The results are summarized in Table 1 , and provide the basis for estimating the long-run parameters of the CLRM.

Table 1: Results of CLRM estimation

\begin{tabular}{lcccc}
\hline & $\begin{array}{c}\text { Incremental } \\
\text { WALR }\end{array}$ & $\begin{array}{c}\text { Outstanding } \\
\text { WALR }\end{array}$ & $\begin{array}{c}\text { Incremental } \\
\text { WADR }\end{array}$ & $\begin{array}{c}\text { Outstanding } \\
\text { WADR }\end{array}$ \\
\hline Intercept & 2.6169 & 4.0960 & -0.7471 & -2.6278 \\
t-statistic & 8.4377 & 12.6550 & -1.8934 & -8.6345 \\
(Prob.) & $(0.0000)$ & $(0.0000)$ & $(0.0624)$ & $(0.0000)$ \\
TB6M & 0.8868 & 0.7476 & 0.6566 & 0.6878 \\
t-statistic & 31.2423 & 25.2380 & 18.1835 & 24.6923 \\
(Prob.) & $(0.0000)$ & $(0.0000)$ & $(0.0000)$ & $0.0000)$ \\
R-squared & 0.9330 & 0.9009 & 0.8252 & 0.8970 \\
Adj. R-squared & 0.9321 & 0.8995 & 0.8227 & 0.8955 \\
Durbin-Watson & 0.8230 & 0.3701 & 0.5463 & 0.2934 \\
\hline
\end{tabular}

Source: Authors' calculations.

The different tests applied confirm all the CLRM assumptions, with the exception of the no-autocorrelation assumption, which is violated in all four regressions. There is positive autocorrelation in the regression results above, which is evident from the Durbin-Watson statistic. Generating a correlogram for each endogenous variable reconfirms the autoregression function at the first lag. Gujarati and Sangeetha (2007, pp. 822-827) do not, however, take into consideration the impact of autocorrelation, and identify the estimated (static) parameter as the long-run equilibrium relation. Additionally, the normality-of-errors assumption required for certain econometric tests is not fulfilled for the incremental WALR regression equation. The results are summarized in Table 2.

Table 2: Jarque-Bera (J-B) test (H0: normal distribution of errors)

\begin{tabular}{lcccc}
\hline & $\begin{array}{c}\text { Incremental } \\
\text { WALR }\end{array}$ & $\begin{array}{c}\text { Outstanding } \\
\text { WALR }\end{array}$ & $\begin{array}{c}\text { Incremental } \\
\text { WADR }\end{array}$ & $\begin{array}{c}\text { Outstanding } \\
\text { WADR }\end{array}$ \\
\hline J-B statistic & 15.1705 & 3.2451 & 1.1313 & 0.4447 \\
(Prob.) & $(0.0005)$ & $(0.1973)$ & $(0.5679)$ & $(0.8006)$ \\
\hline
\end{tabular}

Source: Authors' calculations. 
The nonnormality of errors for the incremental WALR regression is not considered to have an impact on our analysis because the data is considered to be asymptotic. As Brooks (2008, p. 164) points out, for sufficiently large samples, the normality-of-errors assumption is virtually inconsequential based on the central limit theorem. This is confirmed by Gujarati and Sangeetha (2007, p. 346) with the additional comment that it is vital to assume fixed exogenous variable values in repeated trials and homoskedasticity (error variance to be constant).

The $\mathrm{ADF}^{3}$ test is then applied to test for the presence of a unit root, determining the stationarity of each individual series in levels. The results confirm that all the variables are nonstationary in levels but are stationary in the first difference or I(1) (see Table 3).

Table 3: Results of ADF test (H0: unit root)

\begin{tabular}{lccccc}
\hline & TB6M & $\begin{array}{c}\text { Incremental } \\
\text { WALR }\end{array}$ & $\begin{array}{c}\text { Outstanding } \\
\text { WALR }\end{array}$ & $\begin{array}{c}\text { Incremental } \\
\text { WADR }\end{array}$ & $\begin{array}{c}\text { Outstanding } \\
\text { WADR }\end{array}$ \\
\hline $\begin{array}{l}\text { In level: ADF } \\
\text { statistic }\end{array}$ & -0.9007 & -1.2317 & -1.1008 & -1.9023 & -1.6885 \\
(Prob.) & $(0.7826)$ & $(0.6561)$ & $(0.7112)$ & $(0.3295)$ & $(0.4326)$ \\
$\begin{array}{l}\text { In first difference: } \\
\text { ADF statistic }\end{array}$ & -8.9680 & -3.5656 & -3.7396 & -10.5740 & -5.7210 \\
(Prob.) & & & & & \\
\hline
\end{tabular}

Source: Authors' calculations.

Next, the errors $\left(u l_{t}\right.$ and $\left.u d_{t}\right)$ generated from equations (1) and (2) are tested separately using the ADF. The results show that all four regression errors are stationary in levels, confirming the combined integration. Table 4 summarizes these findings.

Table 4: Augmented Dickey-Fuller (ADF) Test (H0: Unit Root)

\begin{tabular}{lcccc}
\hline & $\begin{array}{c}\text { Incremental } \\
\mathrm{ul}_{\mathrm{t}}\end{array}$ & $\begin{array}{c}\text { Outstanding } \\
\mathrm{ul}_{\mathrm{t}}\end{array}$ & $\begin{array}{c}\text { Incremental } \\
\mathrm{ud}_{\mathrm{t}}\end{array}$ & $\begin{array}{c}\text { Outstanding } \\
\mathrm{ud}_{\mathrm{t}}\end{array}$ \\
\hline At Level: ADF Statistic & $-\mathbf{5 . 0 4 0 2}$ & $-\mathbf{3 . 7 2 5 1}$ & $-\mathbf{2 . 6 6 4 6}$ & $-\mathbf{2 . 6 5 8 7}$ \\
(Prob.) & $(0.0000)$ & $(0.0003)$ & $(0.0083)$ & $(0.0085)$ \\
\hline
\end{tabular}

Source: Authors Calculation ${ }^{3}$ The Dickey Fuller (DF) test is not used to test for a unit root because it is not powerful enough to
overcome the violation of the no-autocorrelation assumption. See Dickey and Fuller (1979) for details. 
The EG test is carried out to confirm the cointegration between the variables of each equation. The first step is to run the CLRM and estimate the error (residual) series $u l_{t}$ and $u d_{t}$ for the lending and deposit channels, respectively. These series have already been estimated in equations (1) and (2). The second step is to run the following auxiliary regressions:

$$
\begin{array}{ll}
\text { Lending } & \Delta u l_{t}=\tau_{1} u l_{t-1}+\varepsilon l_{t} \\
\text { Deposit } & \Delta u d_{t}=\tau_{2} u d_{t-1}+\varepsilon d_{t}
\end{array}
$$

where $\Delta$ represents the first difference between the error values calculated from equations (1) and (2), the $\tau$ terms are the computed t-statistic values calculated using the EG test, and $\varepsilon l_{t}$ and $\varepsilon d_{t}$ are the residuals from the auxiliary regressions of the lending and deposit channels, respectively. The results of the second step of the EG test are summarized in Table 5.

Table 5: Results of EG test (second-step estimates)

\begin{tabular}{lcccc}
\hline & $\begin{array}{c}\text { Incremental } \\
\text { WALR }\end{array}$ & $\begin{array}{c}\text { Outstanding } \\
\text { WALR }\end{array}$ & $\begin{array}{c}\text { Incremental } \\
\text { WADR }\end{array}$ & $\begin{array}{c}\text { Outstanding } \\
\text { WADR }\end{array}$ \\
\hline$u_{t-1}$ & -0.4700 & -0.2493 & -0.2903 & -0.1661 \\
$\mathrm{t}$-statistic & -5.0402 & -3.7251 & -3.5400 & -2.6587 \\
EG critical $(\tau=\mathrm{t})$ value at $1 \%=-2.5899$ & & & \\
\hline
\end{tabular}

Source: Authors' calculations.

The computed values are negative (as mentioned in the literature) and significant relative to the 1 percent critical value of -2.5899 . The regressions in equations (1) and (2) are, therefore, cointegrated, confirming that the results are not spurious. The regression coefficients or $\beta$ terms estimated from equations (1) and (2) can be considered long-run parameters and, hence, there is equilibrium at least in the long run.

Having confirmed the cointegration, we apply an ECM to estimate the short-run parameters, using the following regressions:

$$
\begin{array}{ll}
\text { Lending } & \triangle W A L R=\psi_{1}+\psi_{2} \Delta T B 6 M+\psi_{3} u l_{t-1}+e_{1 t} \\
\text { Deposit } & \triangle W A D R=\psi_{4}+\psi_{5} \Delta T B 6 M+\psi_{6} u d_{t-1}+e_{2 t}
\end{array}
$$


where $\Delta$ represents the first difference between the current and lagged values of WALR, WADR, and TB6M; the $\psi$ terms are the slope coefficients; $u l_{t-1}$ and $u d_{t-1}$ are the first-lag error values estimated from equations (1) and (2), respectively; and $e_{1 t}$ and $e_{2 t}$ are the residuals from equations (5) and (6), respectively.

Table 6 gives the empirical parameter estimates of the ECM.

Table 6: ECM estimation

\begin{tabular}{ccccc}
\hline & $\begin{array}{c}\text { Incremental } \\
\text { WALR }\end{array}$ & $\begin{array}{c}\text { Outstanding } \\
\text { WALR }\end{array}$ & $\begin{array}{c}\text { Incremental } \\
\text { WADR }\end{array}$ & $\begin{array}{c}\text { Outstanding } \\
\text { WADR }\end{array}$ \\
\hline Intercept & 0.0571 & 0.0633 & 0.0353 & 0.0447 \\
t-statistic & 1.4663 & 4.1455 & 0.7115 & 2.8795 \\
(Prob.) & $(0.1472)$ & $(0.0001)$ & $(0.4792)$ & $(0.0053)$ \\
$\Delta$ TB6M & 0.3727 & 0.1508 & 0.3058 & 0.1874 \\
t-statistic & 4.1367 & 4.3507 & 2.6199 & 5.3188 \\
(Prob.) & $(0.0001)$ & $(0.0000)$ & $(0.0108)$ & $(0.0000)$ \\
$u_{t-1}$ & -0.3655 & -0.1818 & -0.2195 & -0.1064 \\
t-statistic & -4.5761 & -6.1487 & -2.6884 & -3.3136 \\
(Prob.) & $(0.0000)$ & $(0.0000)$ & $(0.0090)$ & $(0.0015)$ \\
R-squared & 0.3130 & 0.4260 & 0.1384 & 0.3413 \\
Adj. R-squared & 0.2927 & 0.4092 & 0.1131 & 0.3220 \\
Durbin-Watson & 1.7269 & 0.6565 & 2.3956 & 1.4187 \\
\hline
\end{tabular}

Source: Authors' calculations.

The above findings reveal that the errors are significant even at a 1 percent level of significance, thus reconfirming the use of the estimated $\triangle \mathrm{TB} 6 \mathrm{M}$ parameters as short-run pass-through estimates. The findings indicate the impact on the endogenous variables in the short run based on a 100 bps (1 percent) increase in the policy rate proxy or policy shock.

To confirm whether there is a complete pass-through in market retail rates due to a policy shock in the long run, the estimated parameters ( $\beta$ terms) of market lending and deposit rates from equations (1) and (2), respectively, are tested using the Wald coefficient test (Table 7). 
Table 7: Results of Wald test (H0: $\beta=1)$

\begin{tabular}{lcccc}
\hline & $\begin{array}{c}\text { Incremental } \\
\text { WALR }\end{array}$ & $\begin{array}{c}\text { Outstanding } \\
\text { WALR }\end{array}$ & $\begin{array}{c}\text { Incremental } \\
\text { WADR }\end{array}$ & $\begin{array}{c}\text { Outstanding } \\
\text { WADR }\end{array}$ \\
\hline F-statistic & 15.8847 & 72.5549 & 90.3648 & 125.5990 \\
(Prob.) & $(0.0002)$ & $(0.0000)$ & $(0.0000)$ & $(0.0000)$ \\
\hline
\end{tabular}

Source: Authors' calculations.

The Wald coefficient test's null hypothesis implies complete interest rate pass-through $(\mathrm{H} 0: \beta=1)$ to market retail rates in the long run. The results reveal that the estimated parameters in Table 1 are, on average, not equal to 1 . Hence, complete pass-through from a policy shock to Pakistan's financial system in the long run does not hold for both the lending and deposit channels, as indicated by the probability values in Table 7. We therefore reject the null hypothesis of complete pass-through to market retail rates. This poses several questions for future research concerning the applicability of the interest rate channel in the context of Pakistan, the reason(s) for incomplete pass-through, and the financial markets' competition level and practices, etc.

Finally, we use the VECM IRF to determine the speed of the shortrun pass-through. Figure 1 shows its estimated duration and the variations in the endogenous variables due to a policy rate shock of $100 \mathrm{bps}$ (1 percent). 
Figure 1: Impulse response functions
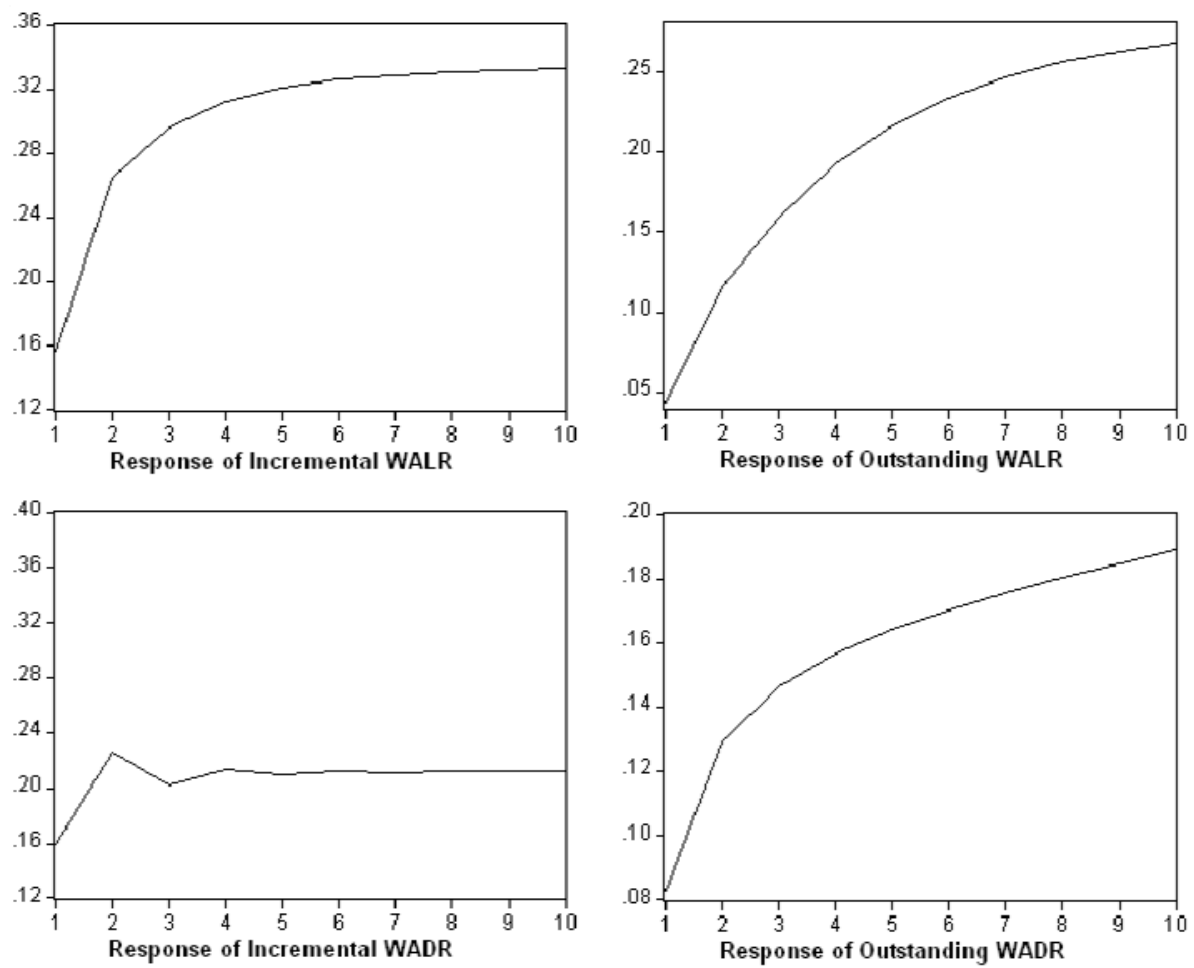

Source: Authors' calculations.

In the short run, on average, a 100 bps increase in the TB6M leads to a 33 bps (approximate) increase in the incremental WALR over six months. Similarly, a 100 bps increase in the TB6M in the short run leads to an average 25 bps (approximate) increase in the outstanding WALR over seven months from the time of the policy shock. In terms of the deposit channel, on average, there is a 21 bps (approximate) increase in the incremental WADR over four months, which is thereafter consolidated at this level in the short run. A 100 bps policy shock leads, on average, to a 17 bps (approximate) increase in the outstanding WADR over six months.

\section{Inferences and Discussion}

We have found evidence that, in the long run, the incremental WALR increases by 89 bps and the outstanding WALR by 75 bps (see Table 1) on average due to a $100 \mathrm{bps}$ increase in the policy rate proxy. In the short run, the incremental WALR increases by 37 bps on average compared to a 
15 bps increase in the outstanding WALR - this is as expected because the outstanding WALR includes previous-period loans and investments on which the rate of return is fixed either till the maturity of the loan contract or the particular time agreed in the loan contract. ${ }^{4}$ The speed of passthrough in the short run for the incremental WALR with an increase of 33 bps is six months, while an increase of 25 bps takes seven months for the outstanding WALR. It is interesting to note that the ECM's short-run parameter for the outstanding WALR is $15 \mathrm{bps}$ compared to $25 \mathrm{bps}$ yielded by the VECM, which is a robust model.

In economies where fiscal indiscipline is high, as in Pakistan's case, the pass-through for lending rates is incomplete mainly because banks are determined to earn higher returns by investing in (almost) no-risk sovereign bonds and securities, rather than lending to the risky private sector and charging borrowers a risk premium (see Faini, 2005, in relation to the euro area, and Akyurek, Kutan, \& Yilmazkuday, 2011, in the context of the Turkish economy).

Additionally, when government borrowings exceed market expectations, increasing the associated risk, there is an insignificant difference in interest rate yields from government financing and lending to other financial institutions. This is evident in the difference between the TB6M and KIBOR ${ }^{5}$ six-month rates, which in June 2011 stood at a meager 5 bps. ${ }^{6}$ The rate of return on government securities remains fixed throughout the term of the bond or security, and despite a change in the benchmark interest rate and adjustment in the price of the security by secondary market forces according to the policy rate change, lending rates in the long run tend to have a smaller impact associated with policy shocks. This is a possible reason for the incomplete pass-through in the lending channel.

With reference to the deposit channel of the pass-through, the incremental WADR increases by 66 bps compared to the outstanding WADR, which increases by 69 bps on average in the long run following a $100 \mathrm{bps}$ increase in the policy rate proxy. This is unexpected and may be

\footnotetext{
${ }^{4}$ Several lending products in Pakistan are based on flexible interest rates that are revised annually, biannually, or quarterly.

${ }^{5}$ The KIBOR is the Karachi interbank offered rate- the reference rate for the corporate lending of funds between financial institutions in Pakistan.

${ }^{6}$ The difference is calculated using the TB6M OMO conducted by the SBP on 29 June, i.e., a yield of 13.7283 percent and the corresponding KIBOR of 13.78 percent on the same date.
} 
due to delayed consumption decisions in the long run by parties who have invested in bank deposits; it is unlikely in the short run due to precautionary consumption demand, but needs to be studied further in detail. In the short run, the incremental WADR increases by 31 bps compared to a 19 bps increase in the outstanding WADR, which is as expected. The speed of the pass-through in the short run is four months for the incremental WADR, yielding an increase of $21 \mathrm{bps}$, while an increase of 17 bps occurs over six months in the case of the outstanding WADR.

Due to the SBP's higher MCR requirement to safeguard depositors' funds with banks - which seems appropriate given the current financial turmoil-the banking industry has experienced several mergers and acquisitions. This has resulted in lower competition within the banking system and has induced banks not to pass on the increase in policy rate to their depositors. At the same time, depositors concerned about the financial health of the banks are less willing to place their deposits with smaller banks (who are in need of fresh deposits) at a higher deposit rate due to the higher associated risk. This pushes the WADR downward, although the larger banks may still offer a lower or minimum deposit rate of 5 percent on savings deposits as stipulated by the SBP.

Interestingly, there is an opportunity for scheduled banks to raise public deposits at a rate closer to the incremental WADR and park these at the SBP's repo rate of 11 percent. These earn an overnight marginal return, and as of May 2011 yield easy earnings at a 3.55 percent rate of return on carrying out such transactions. Additionally, the spread of the banking sector stands at high levels of 6.76 percent between the incremental WALR and WADR, and 7.65 percent on the outstanding WALR and WADR as on May 2011, again indicating the inefficiency and low degree of competition in Pakistan's banking sector.

Theoretically, government borrowings need to be curtailed and the fiscal and monetary policies' stance should complement one another. Significant government borrowings may lead to supply-push inflation in the long run, when the private sector is unwilling to invest at a higher cost of capital, which in turn results in a lower level of output compared to aggregate demand. Although this point remains beyond the scope of this paper, it is vital that future empirical investigations examine the impact of government borrowings on market rates and the economy itself. 


\section{Conclusion}

The interest rate pass-through from a policy shock to the market lending and deposit rates is incomplete in Pakistan, even in the long run. There is evidence that changes in the policy rate have a significant impact on the market lending and deposit rates. Although the pass-through on the lending side is reasonably higher (close to complete) than on the deposit side, it remains incomplete for both lending and deposit channels. The higher pass-through to lending and the lower pass-though to the deposit channel both lead to a higher interest rate spread for the country's banking industry. This may reduce the effectiveness of the monetary policy stance and conduct, and lead to lower banking competition. The speed of the passthrough is also higher on the lending side both in the short and long run.

Based on the analysis above, we can reject the null hypotheses ( $\mathrm{H} 1$ and H2) as policy rate shocks are seen to have a positive significant impact on market lending and deposit rates, implying that the interest rate passthrough is active in Pakistan.

\section{Limitations and Road Ahead}

The limitations of this study point to areas for further empirical investigation to generate improved policy implications:

- Our empirical analysis is based on a contractionary policy stance. Adding data related to an expansionary monetary policy would provide a comparative analysis of the impact of policy rate shocks on market retail rates.

- A structural shock by the SBP (BPRD Circular No. 07 of 2008) caused by placing a minimum deposit return of 5 percent on all savings cannot be taken into account by the ECM, as the second-step differencing of the dummy variable will result in zero values. However, a longer time series could be used to analyze the data separately in two parts, once sufficient observations are available.

- Our findings are based on the current contractionary policy stance, which might not support accurate policy formulation if the policy stance were to change, or if it were affected by a policy decision or other economic factors with a significant impact on the interest rate pass-through. 
- Studying the impact of government borrowings from the central bank and financial system would support the preparation of a better, more influential monetary policy in Pakistan.

\section{Policy Recommendations}

Based on our analysis, we present the following recommendations and avenues for further research on improving the financial market's effectiveness and interest rate pass-through in Pakistan.

It is important to ensure that the MCR level will safeguard public deposits. At the same time, some policy measure is required to bring the interest rate spread of the banking system around to the regional level, to pass on policy shocks to market retail rates, which could improve the effectiveness of monetary policy conduct in Pakistan. One possible measure could be the use of a flexible minimum deposit rate directly linked to the key policy rate or DR.

It is also important to highlight once again that our analysis and policy recommendations apply only to a contractionary monetary policy-once there is a structural change in the economic environment of Pakistan, it may be necessary to re-examine the interest rate pass-through for appropriate policy analysis and recommendation. Hence, our results should not be generalized. 


\section{References}

Agha, A. I., Ahmed, N., Mubarik, Y. A., \& Shah, H. (2005). Transmission mechanism of monetary policy in Pakistan. State Bank of Pakistan Research Bulletin, 1(1), 1-23.

Akyurek, C., Kutan, A. M., \& Yilmazkuday, H. (2011). Can inflation targeting regimes be effective in developing countries? The Turkish experience. Journal of Asian Economics, 22(5), 343-355.

Al-Mashat, R., \& Billmeier, A. (2007). The monetary transmission mechanism in Egypt (Working Paper No. 07/285). Washington, DC: International Monetary Fund.

Angeloni, I., Kashyap, A. K., Mojon, B., \& Terlizzese, D. (2003). Monetary transmission in the euro area: Does the interest rate channel explain all? (Working Paper No. 9984). Cambridge, MA: National Bureau of Economic Research.

Arby, M. F., \& Hanif, M. N. (2010). Monetary and fiscal policies coordination: Pakistan's experience. State Bank of Pakistan Research Bulletin, 6(1), 3-13.

Aydin, H. I. (2010). Interest rate pass-through in Turkey. International Research Journal of Finance and Economics, 57, 82-102.

Bernanke, B. S., \& Blinder, A. S. (1992). The federal funds rate and the channel of monetary transmission. American Economic Review, 82(4), 901-921.

Bredin, D., Fitzpatrick, T., \& O'Reilly, G. (2002). Retail interest rate passthrough: The Irish experience. Economic and Social Review, 33(2), 223-246.

Brooks, C. (2008). Introductory econometrics for finance (2nd ed.). Cambridge, UK: Cambridge University Press.

Cheng, K. C. (2006). A VAR analysis of Kenya's monetary policy transmission mechanism: How does the central bank's REPO rate affect the economy? (Working Paper No. 06/300). Washington, DC: International Monetary Fund. 
Cook, S. (2008). Econometric analysis of interest rate pass-through. Applied Financial Economics Letters, 4(4), 249-255.

Dabla-Norris, E., \& Floerkemeier, H. (2006). Transmission mechanisms of monetary policy in Armenia: Evidence from VAR analysis (Working Paper No. 06/248). Washington, DC: International Monetary Fund.

Dickey, D. A., \& Fuller, W. A. (1979). Distribution of the estimators for autoregressive time series with a unit root. Journal of the American Statistical Association, 74(366), 427-431.

Engle, R. F., \& Granger, C. W. J. (1987). Co-integration and error correction: Representation, estimation and testing. Econometrica, 55(2), 251-276.

Espinosa-Vega, M. A., \& Rebucci, A. (2003). Retail bank interest rate passthrough: Is Chile atypical? (Working Paper No. 03/112). Washington, DC: International Monetary Fund.

Faini, R. (2005). Fiscal policy and interest rates in Europe. Economic Policy, 21(47), 443-489.

Fuertes, A.-M., Heffernan, S., \& Kalotychou, E. (2008). How do UK banks react to changing central bank rates? (Mimeo). Swindon, UK: Economic and Social Research Council.

Gujarati, D. N., \& Sangeetha, S. (2007). Basic econometrics (4th ed.). New Delhi, India: Tata McGrawHill.

Hofmann, B., \& Mizen, P. (2004). Interest rate pass-through and monetary transmission: Evidence from individual financial institutions' retail rates. Economica, 71(281), 99-123.

Horváth, B., \& Maino, R. (2006). Monetary transmission mechanisms in Belarus (Working Paper No. 06/246). Washington, DC: International Monetary Fund.

Javid, M., \& Munir, K. (2010). The price puzzle and monetary policy transmission mechanism in Pakistan: Structural vector autoregressive approach. Pakistan Development Review, 49(4, Pt. II), $449-460$. 
Khawaja, I., \& Din, M. (2007). Determinants of interest spread in Pakistan (Working Paper No. 2007:22). Islamabad: Pakistan Institute of Development Economics.

Mishkin, F. S. (1996). The channels of monetary transmission: Lessons for monetary policy (Working Paper No. 5464). Cambridge, MA: National Bureau of Economic Research.

Parkin, M. (2005). Economics (6th ed.). New York, NY: Addison Wesley.

Poddar, T., Sab, R., \& Khachatryan, H. (2006). The monetary transmission mechanism in Jordan (Working Paper No. 06/48). Washington, DC: International Monetary Fund.

Qayyum, A., Khan, S., \& Khawaja, I. (2005). Interest rate pass-through in Pakistan: Evidence from transfer function approach. Pakistan Development Review, 44(4, Pt. II), 975-1001.

Selvanathan, A., Selvanathan, S., Keller, G., \& Warrack, B. (2004). Australian business statistics (3rd ed.). Melbourne, Australia: Thomas Nelson.

Sims, C. A. (1980). Macroeconomics and reality. Economica, 48(1), 1-48.

Stanlake, G., \& Grant, S. (2000). Introductory economics (7th ed.). Essex, UK: Pearson Education.

State Bank of Pakistan. (2005). Performance of the banking sector. In Pakistan financial sector assessment (chap. 3, p. 55). Karachi, Pakistan: Author.

Takim, A. (2011). Evaluation of empirical findings measuring the effectiveness of monetary transmission mechanism in Turkey. International Research Journal of Finance and Economics, 61, 85-98.

Tieman, A. (2004). Interest rate pass-through in Romania and other Central European economies (Working Paper No. 04/211). Washington, DC: International Monetary Fund. 